\title{
Pain and distress outcomes in infants and children: a systematic review
}

\author{
N.C.A.C. Oliveira, C.M. Gaspardo and M.B.M. Linhares \\ Departamento de Neurociências e Ciências do Comportamento, Faculdade de Medicina de Ribeirão Preto, \\ Universidade de São Paulo, Ribeirão Preto, SP, Brasil
}

\begin{abstract}
The aim of the present study was to systematically review the recent literature about pain and distress outcomes in children and critically analyze the methodological quality of the reports. The systematic review was based on the PRISMA statement and performed by selecting articles that are indexed in scientific databases. The methodological quality of reports was examined using STROBE statement, for observational studies, and CONSORT statement, for randomized controlled trials. The PedIMMPACT consensus was used to evaluate the psychometric quality of pain instruments. We analyzed 23 empirical studies, including 14 randomized controlled trials, seven cross-sectional studies, and two studies with cohort designs. Fourteen studies included preschool- and schoolchildren, and nine studies included infants. Regarding studies with infants, pain responses were evaluated by heart rate, crying and behavioral observation scales, and distress was evaluated only by salivary cortisol. Fourhanded care and sensorial saturation interventions were used to evaluate efficacy to reduce pain and distress responses. Concerning studies with children, both pain and distress responses were evaluated by self- and hetero-reports, behavioral observation and/or physiological measures. Distraction was effective for reducing pain and distress during burn dressing changes and needle procedures, and healing touch intervention reduced distress and pain in chronic patients. All of the studies scored at least $60 \%$ in the methodological quality assessment. The pain outcomes included measures of validity that were classified as well-established by the PedIMMPACT. This systematic review gathers scientific evidence of distress-associated pain in children. Pain and distress were measured as distinct constructs, and their associations were poorly analyzed.
\end{abstract}

Key words: Children; Development; Distress; Pain; Review

\section{Introduction}

Pain constitutes a global health problem, the relief and treatment of which are recognized as a human right by health organizations, especially the World Health Organization and International Association for the Study of Pain (1). Although there has been an exponential increase in scientific studies on pain assessment and management in recent decades, pain continues to be under-assessed and under-treated in pediatric patients (2-5).

Pain is an adverse and stressful experience that can have a negative impact on child development and quality of life. Acute pain has been shown to be positively associated with distress and anxiety $(6,7)$, and chronic pain with helplessness and depression $(8,9)$. Acute painful procedures are a major source of distress in pediatric patients and may have long-term consequences on behavior (10), memory (11), pain perception (12), and developmental outcomes in children (13).

Previous reviews have evaluated randomized clinical trials (RCTs) with regard to the efficacy of non-pharmaco- logical interventions for pain relief in infants $(14,15)$ and children (16-19). One recent review analyzed studies about factors predicting anticipatory distress to painful medical procedures in children aged 0-18 years old (20). However, these reviews did not have the main propose of analyzing studies that assessed pain and distress outcomes simultaneously in infants and children specifically. A recent review also highlighted the need to improve the methodological quality of studies on the subject, allowing the development of guidelines for clinical practice (21).

Distress factors increase the risk of physiological symptoms, negative memories of pain, fear and noncooperation in future painful procedures, as well as burdening the health system with the management of preventable emotional illnesses (22). Therefore, the aim of the present study was to systematically review the recent literature that assessed both pain and distress outcomes in children and to perform an analysis of the methodological quality of the reports. 


\section{Material and Methods}

\section{Databases}

The systematic search strategy was based on the Preferred Reporting Items for Systematic reviews and Meta-Analysis (PRISMA) statement (23). The first author conducted the literature search, data extraction, and critical appraisal. The other authors reviewed the material. Scientific articles were selected in the PubMed, Web of Science, LILACS, and PsycINFO databases. The following combinations of key words were used for the search: Pain and Stress and Behavior, Pain and Distress and Behavior, Pain and Stress and Development, and Pain and Distress and Development.

The inclusion criteria were empirical studies that included pain and distress outcomes published in the last 5 years (from 2010 to 2015), included samples of children between 0-12 years of age, and were published in English. The exclusion criteria were: review articles, letters, editorials, commentaries, studies that evaluated pain or distress in parents and professionals, studies on pharmacological or epidemiological issues exclusively, and studies in languages other than English.

Figure 1 summarizes the literature review process. The initial database search yielded 712 articles. Of these,
219 were duplicated in other databases. After analyzing 493 abstracts, 462 articles were eliminated according to the exclusion criteria. The major reasons for exclusion were: articles that did not assess both pain and distress outcomes $(n=168)$, theoretical articles $(n=107)$, articles with other age groups $(n=65)$, articles that evaluated pain or distress in parents or professionals $(n=40)$, and studies on pharmacological or epidemiological issues $(n=35)$. Thirty-one full-text articles were then reviewed using the inclusion and exclusion criteria. The reasons for exclusion in this stage are shown in Figure 1. A total of 23 articles were finally selected for this systematic review.

\section{Data treatment}

Data extraction was performed to collect information regarding the purpose of the study, theoretical framework, intervention, design, methods, analysis, and findings. The methodological quality of the studies was examined according to the following methodological guidance reports: Strengthening the Reporting of Observational studies in Epidemiology (STROBE) statement (24) for observational studies and the Consolidated Standards of Reporting Trials (CONSORT) statement (25) for RCTs. The total score for STROBE and CONSORT was calculated for each study. The maximum total score was 22 for STROBE and 37 for

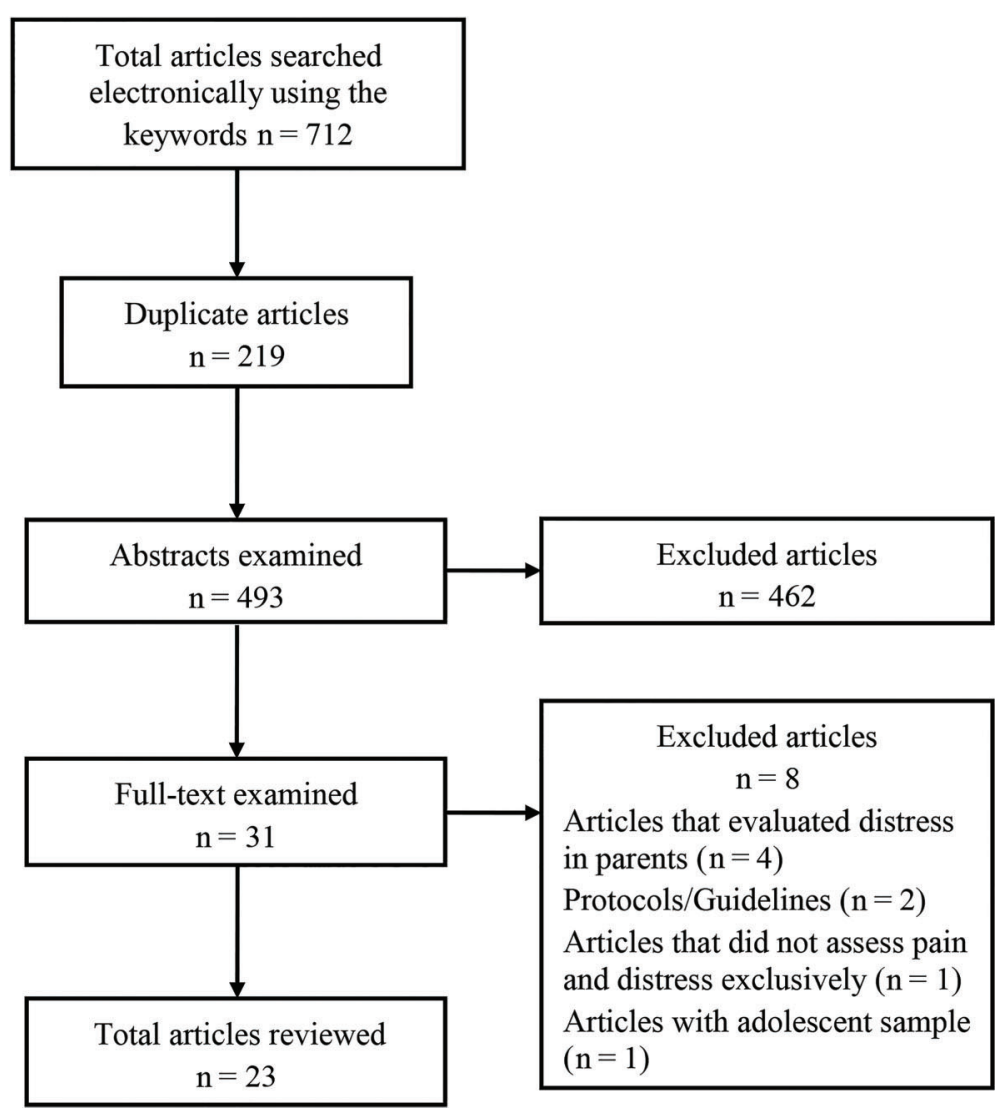

Figure 1. Flowchart of the search strategy used in the review. 
CONSORT. A higher percentage of items conforming to the guidelines represent higher methodological quality.

The Pediatric Initiative on Methods, Measurement, and Pain Assessment in Clinical Trials (PedIMMPACT) consensus was used to determine the psychometric quality of instruments that were used in the studies to evaluate pain $(26,27)$. The PedIMMPACT consensus establishes criteria regarding the quality of pain assessment instruments, classifying them as well-established, approaching wellestablishment, and promising, based on the validity, reliability, and measurement parameters detailing.

\section{Results}

\section{Characteristics of the studies}

Most of the articles were from the United States $(n=9$, $39 \%)$, followed by Canada ( $n=3,13 \%)$, Australia $(n=2,9 \%)$, and Sweden $(n=2,9 \%)$. The other seven articles were published in different countries. With regard to the methodological designs of the studies, $14(61 \%)$ of the articles were RCTs (27-40), 7 (30\%) used a cross-sectional design (41-47) and $2(9 \%)$ used a cohort design $(48,49)$.

Fourteen studies $(61 \%)$ included children of preschool and school age (3-12 years old) (28-30,32,34,36,38, $40,41,43,44,47,48,50)$, and $9(39 \%)$ included infants $(0-2$ years old) $(31,33,35,37,39,42,45,46,49)$. The majority of the studies assessed acute pain during medical procedures $(n=20,87 \%)$. Only three studies $(13 \%)$ evaluated chronic pain conditions $(41,43,48)$.

Among the 23 studies analyzed, 15 (65\%) used selfreported and/or hetero-reported instruments to measure pain intensity, 11 studies (48\%) applied behavioral assessments of pain, and 7 studies (30\%) used physiological measures. With regard to distress outcomes, 12 studies $(52 \%)$ used physiological measures (e.g., salivary cortisol) to measure distress, $8(35 \%)$ applied behavioral assessments of distress, and 6 (26\%) used children's self-reports and/or caregivers' reports.

\section{Methodological quality of the studies}

Table 1 shows the methodological quality of the studies. All conformed with at least $60 \%$ of the CONSORT and STROBE statements. Of the 14 RCTs that were analyzed according to the CONSORT statement, 6 conformed with $60-70 \%$ of the items $(31,33,36,37,39,41)$, 1 conformed with $70-80 \%$ of the items (35), and 7 conformed with $>80 \%$ of the items $(28-30,32,34,38,40)$. These results indicate that the studies reviewed herein had high methodological quality. The nine observational studies evaluated according to the STROBE statement also demonstrated good methodological quality; 4 conformed with $60-70 \%$ of the items $(46,47,48,50), 4$ conformed with $70-80 \%$ of the items (42-45), and 1 conformed with $>90 \%$ of the items (49).

The following weaknesses were identified in the 14 RCTs according to the CONSORT statement: no identification of being a randomized trial in the title $(n=11)$, lack of a trial registration number $(n=10)$, no estimated effect size of the results $(n=8)$, and no description of blinding characteristics $(n=8)$. For the nine observational studies, the following weaknesses were identified according to the STROBE statement: no identification of the study design in the title or abstract $(n=8)$, absence of a flowchart diagram $(n=8)$, absence of sample size information $(n=7)$, and no explanation of how missing data were addressed $(n=7)$.

With regard to the psychometric quality of the pain measurements, all of the instruments that were used in the studies were classified as well-established by the PedIMMPACT consensus.

\section{Main findings of infant studies}

Interventions for pain and distress relief in infants. Table 2 shows the main features and findings of the five RCTs that examined the efficacy of different types of interventions to reduce pain and distress in infants. Three studies compared nonpharmacological interventions (i.e., kangaroo care, four-handed care, and glucose administration) with standard care in a neonatal intensive care unit during endotracheal/nasopharyngeal suctioning procedures in preterm newborns $(31,35,39)$. Two of these studies used a crossover design $(31,35)$. The results showed that kangaroo care and glucose administration were not significantly different from standard care with regard to the reduction of pain and distress $(35,39)$. Four-handed care was more effective than standard care in reducing pain (measured by physiological measures of heart rate and oxygen saturation) and distress outcomes in preterm newborns (39).

The other two studies evaluated different interventions during needle procedures (i.e., heel-lance for blood collection and immunization). Three types of interventions, including pharmacological (fentanyl) and nonpharmacological (facilitated tucking and sensorial saturation) management for pain and distress relief were examined in preterm newborns on postnatal day 2 (33). Fentanyl and sensorial saturation were more effective than facilitated tucking in reducing pain scores. Sensorial saturation was more effective than fentanyl in reducing distress scores. McGowan et al. (37) assessed two different needle techniques (simultaneous and sequential) that were applied during immunizations in infants. The main findings showed that the simultaneous technique was more effective than the sequential technique in reducing pain and distress scores (measured by parental report) in infants at 2-6 months of age.

Evaluation of pain and distress outcomes in infants. Table 3 shows the features and results of the four observational studies that evaluated needle procedures (immunization and heel puncture) in infant samples. Three of the studies performed between-group comparisons $(45,46,49)$, and one study analyzed associations between variables (42). 
Table 1. Methodological quality of the studies based on the percentage of conforming items of the CONSORT and STROBE guidelines $(n=23)$.

\begin{tabular}{|c|c|c|}
\hline Study group/References & CONSORT (\%) & STROBE $(\%)$ \\
\hline \multicolumn{3}{|l|}{ Randomized clinical trials } \\
\hline \multicolumn{3}{|l|}{ Infants } \\
\hline Mitchell et al., 2013 (39) & $67 \%$ & NA \\
\hline Cone et al., 2013 (31) & $66 \%$ & NA \\
\hline Gitto et al., 2011 (33) & $62 \%$ & NA \\
\hline McGowan et al., 2013 (37) & $67 \%$ & NA \\
\hline \multicolumn{3}{|l|}{ Preschool and school age } \\
\hline Brown et al., 2014 (30) & $88 \%$ & NA \\
\hline Nilsson et al., 2013 (40) & $84 \%$ & NA \\
\hline Miller et al., 2011 (38) & $87 \%$ & NA \\
\hline McCarthy et al., 2014 (36) & $68 \%$ & NA \\
\hline Hartling et al., 2013 (34) & $90 \%$ & NA \\
\hline Baxter et al., 2011 (28) & $84 \%$ & NA \\
\hline Beran et al., 2013 (29) & $84 \%$ & NA \\
\hline De Jong et al., 2012 (32) & $87 \%$ & NA \\
\hline Wong et al., 2013 (41) & $69 \%$ & NA \\
\hline \multicolumn{3}{|l|}{ Cross-sectional and cohort } \\
\hline \multicolumn{3}{|l|}{ Infants } \\
\hline Castral et al., 2012 (42) & NA & $77 \%$ \\
\hline Mehler et al., 2015 (45) & NA & $77 \%$ \\
\hline Grunau et al., 2010 (49) & NA & $94 \%$ \\
\hline Schuller et al., 2012 (46) & NA & $65 \%$ \\
\hline \multicolumn{3}{|l|}{ Preschool and school age } \\
\hline McCarthy et al., 2010 (44) & NA & $77 \%$ \\
\hline Connelly and Bickel, 2011 (43) & NA & $74 \%$ \\
\hline Telli et al., 2015 (47) & NA & $67 \%$ \\
\hline Smith et al., 2015 (50) & NA & $68 \%$ \\
\hline Zhao et al., 2015 (48) & NA & $61 \%$ \\
\hline
\end{tabular}

NA: not applicable. CONSORT: Consolidated Standards of Reporting Trials; STROBE: Strengthening the Reporting of Observational studies in Epidemiology.

Very preterm infants (infants born less than 32 weeks of gestational age) presented less pain reactivity, lower pain thresholds, and lower distress compared with fullterm infants during immunization procedures (45). Grunau et al. (49) observed lower distress responses during immunization procedures in boys who were born extremely preterm or with a very low gestational age compared with boys who were born full-term and then evaluated at 4 months of age.

Distress and pain responses in newborns were evaluated during the early postpartum period according to the mode of delivery. Newborns who were delivered vaginally presented higher pain scores (measured by observational scales) and distress scores during heel puncture procedures compared with infants in the elective cesarean section group (46).

The relationship between maternal factors and pain and distress responses in preterm infants who received maternal kangaroo care during heel puncture procedures was investigated by Castral et al. (42). High levels of salivary cortisol in mothers before the heel puncture procedure were correlated with high levels of salivary cortisol in neonates after the procedure and high pain expression during the procedure.

\section{Main results of children studies}

Interventions for pain and distress relief in children. Table 4 presents the characteristics and results of the nine RCTs with children samples. The first three studies in Table 4 examined different interventions during wound dressing procedures in pediatric burn patients. Interventions that were based on distraction (i.e., Ditto intervention, Multimodal Distraction, and Serious gaming) were more effective than standard care and another intervention (i.e., lollipops) in reducing pain (measured by combined tools) $(30,38,40)$ and distress $(38,40)$.

The other four studies evaluated different interventions during needle procedures (i.e., intravenous insertion, 
Table 2. Main findings of randomized clinical trials that assessed pain and distress responses in infants ( $n=5)$.

\begin{tabular}{|c|c|c|c|c|c|}
\hline $\begin{array}{l}\text { Sample } \\
\text { Groups; n; GA; age }\end{array}$ & $\begin{array}{c}\text { Painful } \\
\text { procedure }\end{array}$ & Pain measure & $\begin{array}{l}\text { Distress } \\
\text { measure }\end{array}$ & $\begin{array}{c}\text { Pain } \\
\text { management }\end{array}$ & Main results \\
\hline \multicolumn{6}{|l|}{ Mitchell et al., 2013 (39) } \\
\hline $\begin{array}{l}\text { - Kangaroo care (KC); 19; } \\
\text { 27-30 wks; <5 days } \\
\text { - Standard care (SC); 19; } \\
\text { 27-30 wks; <5 days }\end{array}$ & $\begin{array}{l}\text { Endotracheal or } \\
\text { nasopharyngeal } \\
\text { suctioning }\end{array}$ & PIPP scale & $\begin{array}{l}\text { Salivary } \\
\text { cortisol }\end{array}$ & $\mathrm{KC}$ vs SC & $\begin{array}{c}\mathrm{KC}=\mathrm{SC} \text { for pain and } \\
\text { distress }\end{array}$ \\
\hline \multicolumn{6}{|l|}{ Cone et al., 2013 (31) } \\
\hline $\begin{array}{c}\text { - Four-handed care }(\mathrm{FHC}) \\
10 ;<37 \text { wks; }<7 \text { days }\end{array}$ & $\begin{array}{l}\text { Endotracheal } \\
\text { suctioning }\end{array}$ & $\mathrm{HR}, \mathrm{SpO}_{2}$ & $\begin{array}{l}\text { Salivary } \\
\text { cortisol; } \\
\text { ABSS }\end{array}$ & $\mathrm{FHC}$ vs SC & $\begin{array}{c}\mathrm{FHC}<\mathrm{SC} \text { for pain and } \\
\text { distress behavior } \\
\text { (ABSS) }\end{array}$ \\
\hline \multicolumn{6}{|c|}{ Ivars et al., 2012 (35) } \\
\hline $\begin{array}{l}\text { - Preterm glucose (PT); 11; } \\
\quad<37 \text { wks; <28 days } \\
\text { - Full-term (FT); > } 37 \text { wks; } \\
\quad 2 \text { days }\end{array}$ & $\begin{array}{l}\text { Nasopharyngeal } \\
\text { suctioning }\end{array}$ & VAS, $\mathrm{HR}, \mathrm{SpO}_{2}$ & $\begin{array}{l}\text { Salivary } \\
\text { cortisol }\end{array}$ & $\begin{array}{l}\mathrm{PT} \text { glucose vs } \mathrm{PT} \text { no } \\
\text { glucose vs FT }\end{array}$ & $\begin{array}{c}\mathrm{PT} \text { glucose }=\mathrm{PT} \text { no } \\
\text { glucose }=\mathrm{FT} \text { for pain and } \\
\text { distress }\end{array}$ \\
\hline \multicolumn{6}{|l|}{ Gitto et al., 2011 (33) } \\
\hline $\begin{array}{l}\text { - Fentanyl (FE); 50; } \\
\text { 27-32 wks; } 2 \text { days } \\
\text { - Facilitated tucking (FT); 50; } \\
\text { - Sensorial saturation (SS); } \\
\text { 27-32 wks; } 2 \text { days }\end{array}$ & $\begin{array}{l}\text { Heel-lance for } \\
\text { blood collection }\end{array}$ & CRIES score & $\begin{array}{l}\text { Cytokine } \\
\text { levels }\end{array}$ & $\mathrm{FE}$ vs FT vs SS & $\begin{array}{c}\mathrm{FE} \text { and } \mathrm{SS}<\mathrm{FT} \text { for } \\
\text { pain } \mathrm{SS}<\mathrm{FE} \text { for } \\
\text { distress }\end{array}$ \\
\hline \multicolumn{6}{|l|}{ McGowan et al., 2013 (37) } \\
\hline $\begin{array}{l}\text { - Intervention care group } \\
\text { (simultaneous); 36; } \\
\text { 2-6 months } \\
\text { - Control care group } \\
\text { (sequential); } 36 ; \\
\text { 2-6 months }\end{array}$ & Immunization & MBPS & VAS distress & $\begin{array}{l}\text { Simultaneous vs } \\
\text { sequential } \\
\text { administration } \\
\text { techniques }\end{array}$ & $\begin{array}{c}\text { Simultaneous } \\
<\text { sequential for } \\
\text { observed pain } \\
\text { Simultaneous= } \\
\text { sequential for distress }\end{array}$ \\
\hline
\end{tabular}

GA: gestational age; wks: weeks; PIPP: Premature Infant Pain Profile; HR: heart rate; $\mathrm{SpO}_{2}$ : oxygen saturation; ABSS: Anderson Behavioral State Scale; VAS: Visual Analogue Scale; CRIES: C: crying, R: requires increased oxygen administration, I: increased vital signs, E: expression, S: sleeplessness; MBPS: Modified Behavior Pain Scale.

venipuncture, and immunization) and reported positive results for the efficacy of distractions in reducing distress and the efficacy of music, a Buzzy ${ }^{\mathbb{R}}$ device (MMJ Labs, USA), and a humanoid robot in relieving pain and distress compared with standard care and the control condition $(28,29,34,36)$. All of these studies used self-reports to assess pain and behavioral observations to assess distress. McCarthy et al. (36) compared three levels of distress risk (low, medium, and high) and three levels of distraction intervention (basic, enhanced, and professional) and found that the groups with low and medium risk for distress benefited more from a distraction. Additionally, when professional distraction was applied, the level of distress was less than when basic or enhanced distraction was applied.

Only one study examined two different types of massage (with mandarin oil or carrier oil) for the relief of pain and distress under a postoperative care condition (32). No significant difference was found between these two massage techniques and standard care in children with craniosynostosis. In contrast, Wong et al. (41) evaluated two interventions for oncological pain relief in children with cancer, showing that the healing touch intervention was more effective than reading or playing activities in reducing both pain and distress responses that were measured by self-report.

Evaluation of pain and distress outcomes in children. Table 5 presents the characteristics and findings of five observational studies in children. Three studies assessed acute pain conditions $(44,47,50)$, two of which evaluated needle procedures $(44,50)$. McCarthy et al. (44) examined children's pain and distress (measured by combined tools) during an intravenous insertion procedure with parental distraction coaching. Younger age was associated with higher pain and distress. Child impulsivity was associated with high pain intensity. A high level of parental distraction coaching was associated with less distress in children. Pain and distress during a needle procedure 
Table 3. Main findings of cross-sectional and cohort studies on pain and distress responses in infants ( $\mathrm{n}=4$ ).

\begin{tabular}{|c|c|c|c|c|}
\hline $\begin{array}{l}\text { Design/Sample } \\
\text { Groups; n; GA; mean age }\end{array}$ & $\begin{array}{l}\text { Painful } \\
\text { procedure }\end{array}$ & $\begin{array}{l}\text { Pain } \\
\text { measures }\end{array}$ & $\begin{array}{l}\text { Distress } \\
\text { measures }\end{array}$ & Main results \\
\hline \multicolumn{5}{|l|}{$\begin{array}{l}\text { Mehler et al., } 2015 \text { (45) } \\
\text { Cross-sectional }\end{array}$} \\
\hline $\begin{array}{l}\text { - Very preterm (VPT); } 61 ;<32 \text { wks; } \\
\quad 3.6 \text { months } \\
\text { - Late preterm (LPT); } 30 ; \geqslant 32 \text { and } \\
\quad<37 \text { wks; } 3.5 \text { months } \\
\text { - Full-term (FT); 30; } \geqslant 37 \text { and } \\
\quad<42 \text { wks; } 2.7 \text { months }\end{array}$ & Immunization & $\begin{array}{c}\text { BPNS, HR, } \\
\text { withdrawal threshold }\end{array}$ & $\begin{array}{c}\text { Salivary } \\
\text { cortisol }\end{array}$ & $\begin{array}{c}\text { VPT }<\text { LPT and FT for } \\
\text { physiological (HR) and } \\
\text { behavioral (BPNS) pain VPT } \\
<\text { LPT and FT for pain threshold } \\
\text { reactivity LPT }>\text { FT }>\text { VPT for } \\
\text { distress }\end{array}$ \\
\hline \multicolumn{5}{|l|}{ Grunau et al., 2010 (49) } \\
\hline $\begin{array}{l}\text { - Extremely low gestational age } \\
\text { (ELGA); } 29 ; \leqslant 28 \text { wks; } 3.6 \text { months } \\
\text { - Very low gestational age (VLGA); } \\
\text { 39; } 29-32 \text { wks; } 4.5 \text { months } \\
\text { - Full-term; 32; } 38-41 \text { wks; } \\
\quad 4.5 \text { months }\end{array}$ & Immunization & NFCS, HR & $\begin{array}{l}\text { Salivary } \\
\text { cortisol }\end{array}$ & $\begin{array}{l}\text { ELGA=VLGA=Full-term for } \\
\text { pain ELGA and VLGA boys } \\
<\text { Full-term boys for distress }\end{array}$ \\
\hline \multicolumn{5}{|l|}{ Schuller et al., 2012 (46) } \\
\hline $\begin{array}{l}\text { - Elective cesarean section } \\
\text { (ELSC); 112; } 38 \text { wks, } 3 \text { days } \\
\text { - Spontaneous vaginal delivery } \\
\text { (SVD); 107; } 39 \text { wks, } 3 \text { days } \\
\text { - Vacuum extraction (VE); 61; } \\
\quad 28 \text { wks, } 3 \text { days }\end{array}$ & $\begin{array}{c}\text { Heel prick (at first } \\
72 \mathrm{~h} \text { postnatal period) }\end{array}$ & BPNS, EDIN & $\begin{array}{l}\text { Salivary } \\
\text { cortisol }\end{array}$ & $\begin{array}{l}\text { VE >SVD and ELSC for pain } \\
\text { (EDIN) VE > ELSC for distress }\end{array}$ \\
\hline \multicolumn{5}{|l|}{ Castral et al., 2012 (42) } \\
\hline $\begin{array}{l}\text { - Preterm infants }(P T) \text { under } \\
\text { Kangaroo care; } 42 ;<36 \text { wks; } \\
6 \text { days }\end{array}$ & $\begin{array}{l}\text { Heel puncture for } \\
\text { blood collection }\end{array}$ & Cry; NFCS, HR & $\begin{array}{l}\text { Salivary } \\
\text { cortisol }\end{array}$ & $\begin{array}{c}\uparrow \text { Mothers' cortisol levels before } \\
\text { painful procedure } \uparrow \text { PT cortisol } \\
\text { levels after painful procedure and } \\
\uparrow \text { pain (NFCS) during painful } \\
\text { procedure }\end{array}$ \\
\hline
\end{tabular}

GA: gestational age; wks: weeks; NFCS: Neonatal Face Coding Scale; HR: heart rate; EDIN: Echelle Douleur Inconfort Nouveau; BPNS: Bernese Pain Scale for Neonates.

were also examined by Smith et al. (50), who argued that an imbalance in the apelin and endothelin systems contributed to an increase in the number of painful vasoocclusive episodes and baseline pain in children with sickle cell disease.

Pain and distress in pediatric urology patients who were undergoing invasive radiological procedures were examined by Telly et al. (47). Three approaches (topdown, bottom-up, and repeated voiding cystourethrography) were compared during an invasive procedure, and significant differences in pain and distress outcomes were found between groups. However, a negative correlation was found between child distress and child and adult coping behavior, indicating that high child distress was associated with lower child and adult coping behavior.
Only two studies evaluated chronic pain conditions. In school-age children with headache episodes, a high level of distress predicted a higher incidence of headache (43). Children with cerebral palsy (spastic and non-spastic) were assessed during five treatment programs (acupuncture, neurodevelopmental treatment, neuromuscular electrical stimulation, Chinese traditional manipulation, and occupational therapy), which can cause some degree of pain and distress themselves (48). The children in the spastic group presented significantly higher pain than the non-spastic group, especially in the neurodevelopmental treatment group.

\section{Discussion}

The present systematic review provides relevant considerations in children's pain and distress research. 
Table 4. Main findings of randomized clinical trials that evaluated pain and distress responses in children ( $n=9)$.

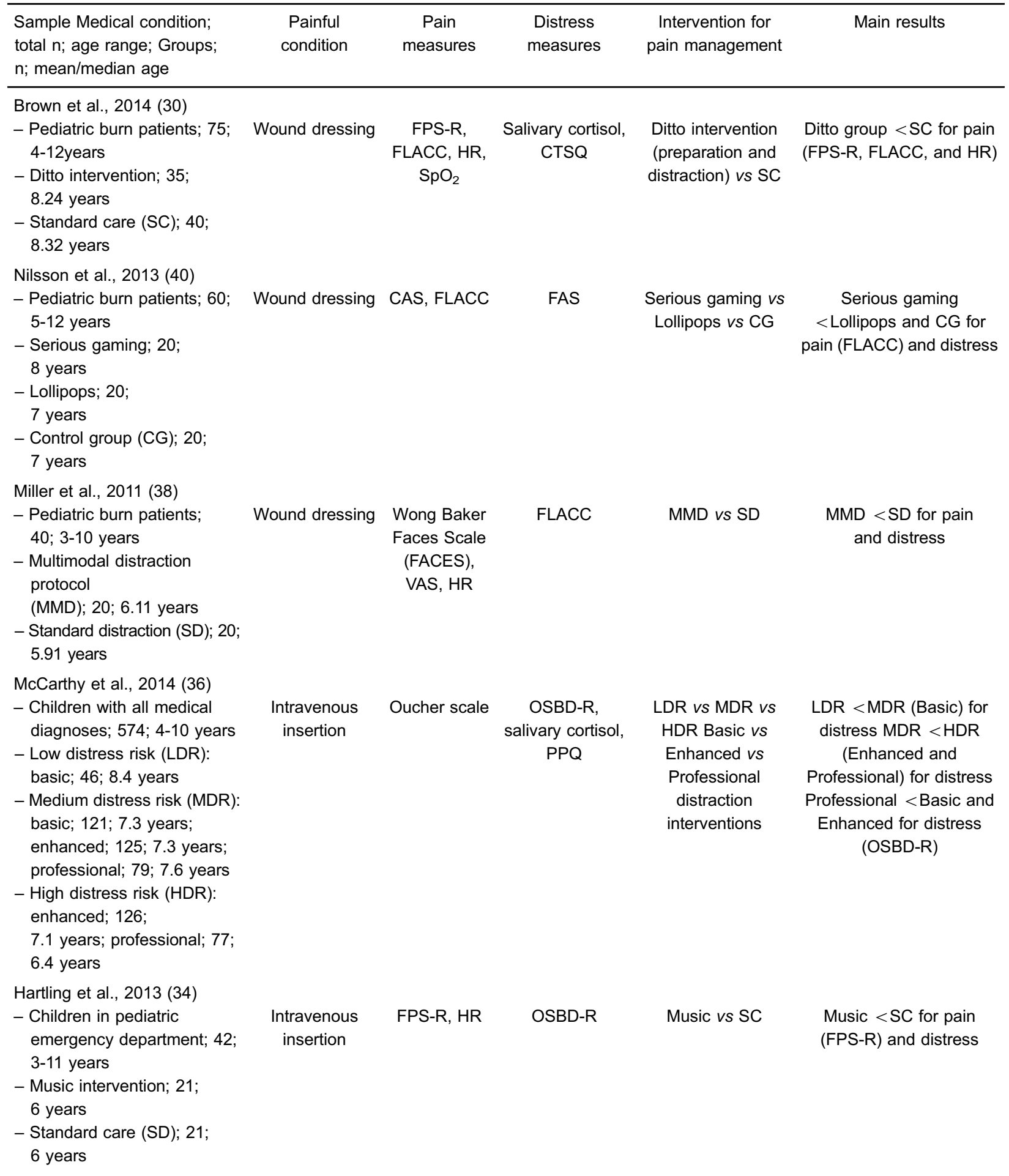


Table 4 Continued.

\begin{tabular}{|c|c|c|c|c|c|}
\hline $\begin{array}{l}\text { Sample Medical condition; } \\
\text { total n; age range; Groups; } \\
\text { n; mean/median age }\end{array}$ & $\begin{array}{l}\text { Painful } \\
\text { condition }\end{array}$ & $\begin{array}{l}\text { Pain } \\
\text { measures }\end{array}$ & $\begin{array}{l}\text { Distress } \\
\text { measures }\end{array}$ & $\begin{array}{l}\text { Intervention for } \\
\text { pain management }\end{array}$ & Main results \\
\hline \multicolumn{6}{|l|}{ Baxter et al., 2011 (28) } \\
\hline $\begin{array}{l}\text { - Children in pediatric } \\
\text { emergency department; } 81 ; \\
\text { 4-18 years } \\
\text { - Device (Buzzy); 41; } \\
\text { 10.10 years } \\
\text { - Standard care (SC); 40; } \\
\text { 9.91 years }\end{array}$ & Venipuncture & FPS-R & OSBD & $\begin{array}{l}\text { Device (Buzzy) } \\
\text { vs SC }\end{array}$ & $\begin{array}{c}\text { Buzzy }<\mathrm{SC} \text { for pain and } \\
\text { distress }\end{array}$ \\
\hline \multicolumn{6}{|l|}{ Beran et al., 2013 (29) } \\
\hline $\begin{array}{l}\text { - Children under } \\
\text { immunization; } 57 ; \\
\text { 4-9 years } \\
\text { - Humanoid Robot; } 28 ; \\
\text { 6.36 years } \\
\text { - Control group (CG); 29; } \\
\text { 6.66 years }\end{array}$ & Immunization & FPS-R & BAADS & $\begin{array}{c}\text { Humanoid robot } \\
\text { vs CG }\end{array}$ & $\begin{array}{l}\text { Humanoid robot }<\mathrm{CG} \\
\text { for pain and distress }\end{array}$ \\
\hline \multicolumn{6}{|l|}{ De Jong et al., 2012 (32) } \\
\hline $\begin{array}{l}\text { - Children with } \\
\text { craniosynostosis; } 59 ; \\
\text { 3-36 months } \\
\text { - Massage with mandarin oil; } \\
\text { 20; } 10.1 \text { months } \\
\text { - Massage with carrier oil; } 20 ; \\
\text { 11.5 months } \\
\text { - Standard care (SC); } 19 ; \\
10.8 \text { months }\end{array}$ & $\begin{array}{l}\text { Postoperative } \\
\text { care }\end{array}$ & $\begin{array}{l}\text { NRS pain, } \\
\text { COMFORT, } \\
\text { HR, mean } \\
\text { arterial } \\
\text { pressure }\end{array}$ & NRS distress & $\begin{array}{l}\text { Massage with } \\
\text { mandarin } \\
\text { oil vs Massage with } \\
\text { carrier oil vs SC }\end{array}$ & $\begin{array}{c}\text { Massage with mandarin } \\
\text { oil=Massage with carrier } \\
\text { oil=SC for pain and } \\
\text { distress }\end{array}$ \\
\hline Wong et al., 2013 (41) & & & & & \\
\hline $\begin{array}{l}\text { - Pediatric oncology patients; } \\
\text { 9; 3-18 years } \\
\text { - Healing touch }(\mathrm{HT}) ; 6 ; \\
\text { 8.83 years } \\
\text { - Reading/activity; } 3 ; \\
\text { 7.33 years }\end{array}$ & Oncological pain & $\begin{array}{l}\text { Wong Baker } \\
\text { Faces Scale }\end{array}$ & $\begin{array}{l}\text { Feeling } \\
\text { Thermometer }\end{array}$ & $\begin{array}{l}\text { HT vs Reading/play } \\
\text { activity }\end{array}$ & $\begin{array}{c}\mathrm{HT}<\text { Reading/play activity } \\
\text { for pain and distress }\end{array}$ \\
\hline
\end{tabular}

NRS: Numerical Rating Scale; HR: heart rate; FLACC: Face, Legs, Activity, Cry, Consolability; SC: standard care; FPS-R: Faces Pain Scale-Revised; CG: control group; CTSQ: Child Trauma Screening Questionnaire; CAS: Color Analogue Scale; FAS: Facial Affective Scale; VAS: Visual Analogue Scale; OSBD-R: Observational Scale of Behavioral Distress-Revised; PPQ: Perception of Procedures Questionnaire; BAADS: Behavioral Approach-Avoidance Distress Scale.

We identified a large number of RCTs, showing a clear concern of the scientific community to design studies to test the efficacy of nonpharmacological interventions for pain relief. Previous reviews have addressed RCTs of non-pharmacological interventions for pain relief in specific age groups $(14,16,18-21)$, without necessarily assessing pain and distress responses simultaneously. The present review found that most RCTs and observational studies had satisfactory methodological quality, conforming with more than $70 \%$ of the items of the CONSORT and STROBE statements.
With regard to methodological controls, most of the studies utilized standard care in routine settings and provided details of the painful procedures, thus contributing to a better understanding of the intervention, context, and findings. With regard to methodological care, we found that the studies used well-established measures based on the PedIMMPACT consensus, thus providing greater reliability of the studies' findings. The criteria for considering a measure as well-established were the following: validity, reliability, measurement accuracy that allows replication, and publication by different groups of researchers 
Table 5. Main findings of cross-sectional and cohort studies on pain and distress responses in children ( $\mathrm{n}=5$ ).

\begin{tabular}{|c|c|c|c|c|}
\hline $\begin{array}{l}\text { Design/Sample Medical } \\
\text { condition; total n; age range } \\
\text { Group; n; mean/median age }\end{array}$ & $\begin{array}{l}\text { Painful } \\
\text { condition }\end{array}$ & $\begin{array}{l}\text { Pain } \\
\text { measures }\end{array}$ & $\begin{array}{l}\text { Distress } \\
\text { measures }\end{array}$ & Main results \\
\hline \multicolumn{5}{|l|}{ McCarthy et al., 2010 (44) } \\
\hline \multicolumn{5}{|l|}{ Cross-sectional } \\
\hline $\begin{array}{l}\text { - Children with all medical } \\
\text { diagnoses under parental } \\
\text { distraction; } 542 ; 4-10 \text { years; } \\
6.95 \text { years }\end{array}$ & $\begin{array}{l}\text { Intravenous } \\
\text { insertion }\end{array}$ & Oucher scale & $\begin{array}{l}\text { OSBD-R, salivary } \\
\text { cortisol, PPQ }\end{array}$ & $\begin{array}{c}\downarrow \text { Age } \uparrow \text { Pain intensity and } \\
\text { distress (OSBD-R) } \uparrow \text { Child } \\
\text { impulsivity } \uparrow \text { Pain intensity } \uparrow \\
\text { Level of parental distraction } \\
\text { coaching } \downarrow \text { Child distress } \\
\text { (OSBD-R) }\end{array}$ \\
\hline \multicolumn{5}{|l|}{ Smith et al., 2015 (50) } \\
\hline $\begin{array}{l}\text { - Children with sickle cell } \\
\text { disease; } 47 ; 2-18 \text { years; } \\
9.98 \text { years }\end{array}$ & Venipuncture & $\begin{array}{c}\text { Wong Baker Faces } \\
\text { Scale; VAS }\end{array}$ & OSBD & $\begin{array}{l}\text { Imbalance in apelin and } \\
\text { endothelin systems } \uparrow \text { Painful } \\
\text { vaso-occlusive episodes and } \\
\text { baseline pain }\end{array}$ \\
\hline \multicolumn{5}{|l|}{ Telli et al., 2015 (47) } \\
\hline $\begin{array}{l}\text { - Pediatric urology patients; } \\
\text { 120; 3-8 years } \\
\text { - Top-down (TD); 60; } 5.2 \text { years } \\
\text { - Bottom-up (BU); 60; } 4.9 \text { years } \\
\text { - Repeated voiding } \\
\text { cystourethrography (R-VCUG); } \\
\text { 544;.6 years }\end{array}$ & $\begin{array}{l}\text { Invasive radiological } \\
\text { procedures (VCUG } \\
\text { and DMSA) }\end{array}$ & FPS-R & CAMPIS-R & $\begin{array}{c}\text { TD=BU=R-VCUG for pain } \uparrow \\
\text { Child distress } \downarrow \text { Child coping } \\
\uparrow \text { Child distress } \downarrow \text { Adult } \\
\text { coping }\end{array}$ \\
\hline \multicolumn{5}{|l|}{ Connelly and Bickel, 2011 (43) } \\
\hline $\begin{array}{l}\text { - Children with headache; } 25 \text {; } \\
\text { 8-17 years; } 12.34 \text { years }\end{array}$ & Headache episodes & $\begin{array}{l}\text { VAS, electronic } \\
\text { diary }\end{array}$ & Facial Affect Scale & $\begin{array}{l}\uparrow \text { Distress intensity } \uparrow \\
\text { Headache occurrence }\end{array}$ \\
\hline \multicolumn{5}{|l|}{ Zhao et al., 2015 (48) } \\
\hline $\begin{array}{l}\text { - Children with cerebral palsy; } \\
\text { 40; } 1-4 \text { years; } 2.27 \text { years } \\
\text { - Spastic; } 21 ; 2.38 \text { years } \\
\text { - Nonspastic; } 19 ; 2.14 \text { years }\end{array}$ & $\begin{array}{c}\text { Pain during } \\
\text { intervention } \\
\text { programs (NDT; } \\
\text { NMES; OT; HA and } \\
\text { CTM) }\end{array}$ & $\begin{array}{c}\text { FLACC; WRTs (pain } \\
\text { sensitivity) }\end{array}$ & Salivary cortisol & $\begin{array}{c}\text { Spastic > Non-spastic for } \\
\text { pain in NDT intervention } \uparrow \\
\text { Distress levels in HA, NDT, } \\
\text { NMES, and CTM } \\
\text { posttreatment in Spastic and } \\
\text { Non-spastic }\end{array}$ \\
\hline
\end{tabular}

VCUG: voiding cystourethrography; DMSA: technetium dimercaptosuccinic acid; CAMPIS-R: Child-Adult Medical Procedure Interaction Scale-Revised; OSBD: Observational Scale of Behavioral Distress; PPQ: Perception of Procedures Questionnaire; NDT: neurodevelopmental treatment; NMES: neuromuscular electrical stimulation; OT: occupational therapy; HA: head acupuncture; CTM: Chinese traditional manipulation.

in peer-reviewed journals $(26,27)$. With regard to pain outcomes, one RCT (30) used only physiological measures to assess pain in infants. Although these indicators are sensitive to pain, they should be considered complementary measures, and not necessarily painspecific (51).

Overall, most of the studies used physiological and behavioral parameters as distress outcomes. The present review found few instruments that measured distress, especially in infants, in which salivary cortisol was the most commonly used measure. It is important to note that when a child feels threatened, there are biobehavioral reactions with physiological responses, including increase in heart rate, blood pressure, and stress hormones (e.g., cortisol) (52). However, future studies should focus on instruments that advance beyond physiological indicators, including behavioral dimensions of distress in infants. 
Most studies assessing distress in pre-school and school phases used observational scales that presented well-established psychometric proprieties (53) and only four studies measured salivary cortisol $(30,36,44,48)$. Few studies used self-reported tools to measure distress outcomes, with a highlight on the use of generic measures, such as Feeling Thermometer, Numerical Rating Scale, Visual Analogue Scale and Facial Affective Scale, which are not distress-specific $(27,32,37,40,41)$. This demonstrates a demand for self-reported instruments that specifically measure distress outcomes in children. Moreover, the terms distress and pain are often used interchangeably. Pain and distress are indeed associated with each other through distinct constructs. Distress is described as a type of negative emotion that could interfere in painful procedures and have psychological implications in a child's development $(18,54)$, but it should be observed separately from other negative emotions, such as pain experience.

A larger number of studies assessing preschool- and schoolchildren rather than infants was found. There is relevant evidence showing that infants who were exposed to painful experiences at very early developmental stages present distress reactivity with a long-term developmental negative impact $(11,13)$.

Another aspect that was highlighted in the present review is the lack of studies on chronic pain compared to studies on acute pain, which were found in a greater number. This may be related to the fact that acute pain is the main complaint of children and parents during medical procedures, and acute pain is intrinsically related to distress in pediatric settings $(55,56)$. Efforts have been made to determine the long-term impact of acute painful

\section{References}

1. IASP (International Association for the Study of Pain). Declaration that access to pain management is a fundamental human right. Montreal: International Pain Summit; 2010.

2. Birnie KA, Chambers CT, Fernandez CV, Forgeron PA, Latimer MA, McGrath $\mathrm{PJ}$, et al. Hospitalized children continue to report undertreated and preventable pain. Pain Res Manag 2014; 19: 198-204, doi: 10.1155/2014/614784.

3. Linhares MBM, Doca FNP, Martinez FE, Carlotti APP, Cassiano RGM, Pfeifer LI, et al. Pediatric pain: prevalence, assessment, and management in a teaching hospital. Braz $J$ Med Biol Res 2012; 45: 1287-1294, doi: 10.1590/S0100879X2012007500147.

4. Stevens BJ, Abbott LK, Yamada J, Harrison D, Stinson J, Taddio A, et al. Epidemiology and management of painful procedures in children in Canadian hospitals. Can Med Assoc J 2011; 183: E403-E410, doi: 10.1503/cmaj.101341.

5. Taylor EM, Boyer K, Campbell FA. Pain in hospitalized children: a prospective cross-sectional survey of pain prevalence, intensity, assessment and management in a Canadian procedures on child behavior and development $(10,11,13)$, which may be associated with the development and maintenance of chronic pain later in life (12).

In conclusion, this systematic review gathers scientific evidence of distress-associated pain in children in different developmental phases, which may contribute to better care for infants and children under painful conditions. The present review has some limitations that should be addressed. First, the review period was restricted to the last 5 years. Second, the studies used different interventions, painful procedures, pain and distress outcome measures, and sample sizes, which may hinder comparisons between studies. Third, we adopted an upper limit for age that consequently excluded studies with adolescents.

Future studies should address chronic pain and develop specific instruments to evaluate distress in infants while maintaining methodological quality to improve the reliability of the findings. Finally, the pain and distress reactivity should be better examined separately, but in the same painful experience context. Furthermore, the data analysis should advance into the associations between pain and distress variables.

\section{Acknowledgments}

The authors gratefully thank the support of the Coordination for Improvement of Higher Education Personnel (CAPES, Brazil), the São Paulo Research Foundation (FAPESP, \#2015/16977-9, Brazil), and The Pain in Child Health Training Consortium (PICH, Canada) to N.C. A.C. Oliveira; CAPES to C.M. Gaspardo, and CNPq to M. B.M. Linhares. pediatric teaching hospital. Pain Res Manag 2008; 13: 25-32, doi: 10.1155/2008/478102.

6. Howard RF. Developmental factors and acute pain in children. In: Justins DM (Editors), Pain 2005: An updated review. Seattle: IASP Press; 2005. p. 283-290.

7. Symreng I, Fishman SM. Anxiety and pain. Pain: Clinical updates 2004; 12: 1-6.

8. Jones AKP. The role of the cerebral cortex in pain perception. In: Justins DM (Editors), Pain 2005: An updated review. Seattle: IASP Press; 2005. p. 59-68.

9. Puccini RF, Bresolin AMB. Dores recorrentes na infância e adolescência. J Pediatr 2003; 79: 65-76, doi: 10.2223/ JPED.1001.

10. Howard RF. Current status of pain management in children. J Am Med Assoc 2003; 290: 2464-2469, doi: 10.1001/ jama.290.18.2464.

11. Kennedy RM, Luhmann J, Zempsky WT. Clinical implications of unmanaged needle-insertion pain and distress in children. Pediatrics 2008; 122: S130-S133, doi: 10.1542/ peds.2008-1055e. 
12. Noel M, Chambers CT, McGrath PJ, Klein RM, Stewart SH. The influence of children's pain memories on subsequent pain experience. Pain 2012; 153: 1563-1572, doi: 10.1016/ j.pain.2012.02.020.

13. Valeri BO, Holsti L, Linhares MBM. Neonatal pain and developmental outcomes in children born preterm: a systematic review. Clin J Pain 2015; 31: 355-362, doi: 10.1097/ AJP.0000000000000114.

14. Pillai Riddell RR, Racine NM, Turcotte K, Uman LS, Horton $\mathrm{RE}$, Din Osmun L, et al. Non-pharmacological management of infant and young child procedural pain. Cochrane Database Syst Rev 2011; 10: CD006275, doi: 10.1002/146518 58.CD006275.pub2

15. Yamada J, Stinson J, Lamba J, Dickson A, McGrath PJ, Stevens B, et al. A review of systematic reviews on pain interventions in hospitalized infants. Pain Res Manag 2008; 13: $413-420$, doi: $10.1155 / 2008 / 232316$

16. Oliveira NCAC, Linhares MBM. Nonpharmacological interventions for pain relief in children: a systematic review. Psychol Neurosci 2015; 8: 28-38, doi: 10.1037/h0101030.

17. Stinson J, Yamada J, Dickson A, Lamba J, Stevens B. Review of systematic reviews on acute procedural pain in children in the hospital setting. Pain Res Manag 2008; 13: 51-57, doi: 10.1155/2008/465891.

18. Uman LS, Chambers CT, McGrath PJ, Kisely S. A systematic review of randomized controlled trials examining psychological interventions for needle related procedural pain and distress in children and adolescents: an abbreviated Cochrane Review. J Pediatr Psychol 2008; 33: 842-854, doi: 10.1093/jpepsy/jsn031.

19. Uman LS, Birnie KA, Noel M, Parker JA, Chambers CT, McGrath PJ, et al. Psychological interventions for needlerelated procedural pain and distress in children and adolescents. Cochrane Database Syst Rev 2013; 10: CD0 05179.

20. Racine N, Pillai Riddell R, Khan M, et al. Systematic review: predisposing, precipitating, perpetuating, and present factors predicting anticipatory distress to painful medical procedures in children. J Pediatr Psychol 2016; 41: 159-181, doi: 10.1093/jpepsy/jsv076.

21. Birnie KA, Noel M, Parker JA, Chambers CT, Uman LS, Kisely SR, et al. Systematic review and meta-analysis of distraction and hypnosis for needle-related pain and distress in children and adolescents. J Pediatr Psychol 2014; 39: 783-808, doi: 10.1093/jpepsy/jsu029.

22. McMurtry CM, Pillai Riddell R, Taddio A, Racine N, Asmundson GJ, Noel M, et al. Far from "just a poke": common painful needle procedures and the development of needle fear. Clin J Pain 2015; 31(10 Suppl): S3-S11, doi: 10.1097/AJP.0000000000000272.

23. Shamseer L, Moher D, Clarke M, Ghersi D, Liberati A, Petticrew $M$, et al. Preferred reporting items for systematic review and meta-analysis protocols (PRISMA-P) 2015: elaboration and explanation. Br Med J 2015; 349: g7647, doi: 10.1186/2046-4053-4-1

24. von Elm E, Altman DG, Egger M, Pocock SJ, Gøtzsche PC, Vandenbroucke JP. The strengthening the reporting of observational studies in epidemiology (STROBE) statement: guidelines for reporting observational studies. $J$ Clin Epidemiol 2008; 61: 344-349, doi: 10.1016/j.jclinepi.2007. 11.008.
25. Schulz KF, Altman DG, Moher D. CONSORT 2010 Statement: updated guidelines for reporting parallel group randomized trials. Ann Int Med 2010; 152: 726-732, doi: 10.7326/ 0003-4819-152-11-201006010-00232.

26. Dworkin RH, Turk DC, Farrar JT, Haythornthwaite JA, Jensen MP, Katz NP, et al. Core outcome measures for chronic pain clinical trials: IMMPACT recommendations. Pain 2005; 113: 9-19, doi: 10.1016/j.pain.2004.09.012.

27. McGrath PJ, Walco GA, Turk DC, Dworkin RH, Brown MT, Davidson $\mathrm{K}$, et al. Core outcome domains and measures for pediatric acute and chronic/recurrent pain clinical trials: PedIMMPACT recommendations. J Pain 2008; 9: 771-783, doi: 10.1016/j.jpain.2008.04.007.

28. Baxter AL, Cohen LL, McElvery HL, Lawson ML, von Baeyer $\mathrm{CL}$. An integration of vibration and cold relieves venipuncture pain in a pediatric emergency department. Pediatr Emerg Care 2011; 27: 1151-1156, doi: 10.1097/PEC.0b013 e318237ace4.

29. Beran TN, Ramirez-Serrano A, Vanderkooi OG, Kuhn S. Reducing children's pain and distress towards flu vaccinations: a novel and effective application of humanoid robotics. Vaccine 2013; 31: 2772-2777, doi: 10.1016/j.vaccine.2013. 03.056 .

30. Brown NJ, Kimble RM, Rodger S, Ware RS, Cuttle L. Play and heal: randomized controlled trial of Ditto ${ }^{\mathrm{TM}}$ intervention efficacy on improving re-epithelialization in pediatric burns. Burns 2014; 40: 204-213, doi: 10.1016/j.burns.2013. 11.024.

31. Cone S, Pickler RH, Grap MJ, McGrath J, Wiley PM. Endotracheal suctioning in preterm infants using four-handed versus routine care. J Obstet Gynecol Neonatal Nurs 2013; 42: 92-104, doi: 10.1111/1552-6909.12004.

32. De Jong $M$, Lucas $C$, Bredero $H$, van Adrichem L, Tibboel $D$, van Dijk M. Does postoperative ' $M$ ' technique massage with or without mandarin oil reduce infants' distress after major craniofacial surgery? J Adv Nurs 2012; 68: 1748-1757, doi: 10.1111/j.1365-2648.2011.05861.x.

33. Gitto E, Pellegrino S, Manfrida M, Aversa S, Trimarchi G, Barberi I, et al. Stress response and procedural pain in the preterm newborn: the role of pharmacological and non-pharmacological treatments. Eur J Pediatr 2011; 171: 927-933, doi: 10.1007/s00431-011-1655-7.

34. Hartling L, Newton AS, Liang Y, Jou H, Hewson K, Klassen TP, et al. Music to reduce pain and distress in the pediatric emergency department: a randomized clinical trial. JAMA Pediatr 2013; 167: 826-835, doi: 10.1001/jamapediatrics. 2013.200.

35. Ivars K, Nelson N, Finnström O, Mörelius E. Nasopharyngeal suctioning does not produce a salivary cortisol reaction in preterm infants. Acta Paediatr 2012; 101: 1206-1210, doi: 10.1111/apa.12001.

36. McCarthy AM, Kleiber C, Hanrahan K, Zimmerman MB, Ersig A, Westhus $\mathrm{N}$, et al. Matching doses of distraction with child risk for distress during a medical procedure: a randomized clinical trial. Nurs Res $J$ 2014; 63: 397-407, doi: $10.1097 /$ NNR.0000000000000056.

37. McGowan A, Cottrell S, Roberts R, Lankshear A. Minimising pain response during routine infant immunisation. $J \mathrm{Com}$ munity Pract 2013; 86: 24-28.

38. Miller K, Rodger S, Kipping B, Kimble RM. A novel technology approach to pain management in children with burns: 
a prospective randomized controlled trial. Burns 2011; 37 : 395-405, doi: 10.1016/j.burns.2010.12.008.

39. Mitchell AJ, Yates CC, Williams DK, Chang JY, Hall RW. Does daily kangaroo care provide sustained pain and stress relief in preterm infants? J Neonatal Perinatal Med 2013; 6: 45-52.

40. Nilsson S, Enskär K, Hallqvist C, Kokinsky E. Active and passive distraction in children undergoing wound dressings. J Pediatr Nurs 2013; 28: 158-166, doi: 10.1016/j.pedn.2012. 06.003.

41. Wong J, Ghiasuddin A, Kimata C, Dickson A, McGrath PJ, Stevens B. The impact of healing touch on pediatric oncology patients. Integr Cancer Ther 2013; 12: 25-30, doi: $10.1177 / 1534735412446864$.

42. Castral TC, Warnock FF, Ribeiro LM, de Vasconcelos MG, Leite AM, Scochi CG. Maternal factors regulating preterm infants' responses to pain and stress while in maternal kangaroo care. Rev Lat Am Enfermagem 2012; 20: 435-443, doi: 10.1590/S0104-11692012000300003.

43. Connelly M, Bickel J. An electronic daily diary process study of stress and health behavior triggers of primary headaches in children. J Pediatr Psychol 2011; 36: 852-862, doi: 10.1093/ jpepsy/jsr017.

44. McCarthy AM, Kleiber C, Hanrahan K, Zimmerman MB, Westhus N, Allen S. Factors explaining children's responses to intravenous needle insertions. Nurs Res J 2010; 59: 407-416, doi: 10.1097/NNR.0b013e3181f80ed5.

45. Mehler K, Ulbrich L, Boerner S, Joachim A, Becker I, Roth B, et al. Multidimensional response to vaccination pain in very preterm, moderate-to-late preterm and full-term infants at age three months. Early Hum Dev 2015; 91: 199-204, doi: 10.1016/j.earlhumdev.2015.01.011.

46. Schuller C, Känel N, Müller O, Kind AB, Tinner EM, Hösli I, et al. Stress and pain response of neonates after spontaneous birth and vacuum-assisted and cesarean delivery. Am J Obstet Gynecol 2012; 207: 416.e3-416.e6, doi: 10.1016/ j.ajog.2012.08.024.

47. Telli $O$, Mermerkaya M, Hajiyev $P$, Aydogdu O, Afandiyev F, Suer $E$, et al. Is top-down vs bottom-up radiological evaluation after febrile urinary tract infection really less stressful for the child and family? Challenging the dogma. J Urol 2015; 193: 958-962, doi: 10.1016/j.juro.2014.10.044.

48. Zhao X, Chen M, Du S, Li H, Li X. Evaluation of stress and pain in young children with cerebral palsy during early developmental intervention programs: a descriptive study. Am J Phys Med Rehabil 2015; 94: 169-175, doi: 10.1097/ PHM.0000000000000252.

49. Grunau RE, Tu MT, Whitfield MF, Oberlander TF, Weinberg $\mathrm{J}, \mathrm{Yu} \mathrm{W}$, et al. Cortisol, behavior, and heart rate reactivity to immunization pain at 4 months corrected age in infants born very preterm. Clin J Pain 2010; 26: 698-704.

50. Smith TP, Schlenz AM, Schatz JC, Maitra R, Sweitzer SM. Modulation of pain in pediatric sickle cell disease: understanding the balance between endothelin mediated vasoconstriction and apelin mediated vasodilation. Blood Cells Mol Dis 2015; 54: 155-159, doi: 10.1016/j.bcmd.2014.11.016.

51. Linhares MBM, Doca FNP. Dor em neonatos e crianças: avaliação e intervenções não farmacológicas [Pain in neonates and children: assessment and non-pharmacological interventions]. Temas em Psicologia 2010; 18: 307-325.

52. Slopen N, McLaughlin KA, Shonkoff JP. Interventions to improve cortisol regulation in children: a systematic review. Pediatrics 2014; 133: 312-326, doi: 10.1542/peds.20131632.

53. Cohen LL, Lemanek K, Blount RL, Dahlquist LM, Lim CS, Palermo TM, et al. Evidence-based assessment of pediatric pain. J Pediatr Psychol 2008; 33: 939-955, doi: 10.1093/ jpepsy/jsm103.

54. Barros L. A dor pediátrica associada a procedimentos médicos: contributos da Psicologia Pediátrica [Pediatric pain associated with medical procedures: contributions of Pediatric Psychology]. Temas em Psicologia 2010; 18: 295-306.

55. Hedström M, Haglund K, Skolin I, von Essen L. Distressing events for children and adolescents with cancer: child, parent, and nurse perceptions. J Pediatr Oncol Nurs 2003; 20: 120-132, doi: 10.1053/jpon.2003.76.

56. Kleiber C, Harper DC. Effects of distraction on childrens' pain and distress during medical procedures: a meta-analysis. Nurs Res 1999; 48: 44-49, doi: 10.1097/00006199$199901000-00007$. 